\title{
Effects of gemcitabine on APE/ref-I endonuclease activity in pancreatic cancer cells, and the therapeutic potential of antisense oligonucleotides
}

\author{
JP Lau ${ }^{1,2}$, KL Weatherdon', V Skalski ${ }^{1,2}$ and DW Hedley ${ }^{* 1,2,3}$ \\ 'Division of Experimental Therapeutics, Ontario Cancer Institute/Princess Margaret Hospital, 610 University Avenue, Toronto, Ontario, Canada M5G \\ 2M9; ${ }^{2}$ Department of Medical Biophysics, University of Toronto, 610 University Avenue, Toronto, Ontario, Canada M5G 2M9; ${ }^{3}$ Department of Medical \\ Oncology and Hematology, Ontario Cancer Institute/Princess Margaret Hospital, 610 University Avenue, Toronto, Ontario, Canada M5G 2 M9
}

\begin{abstract}
Apuriniclapyrimidinic endonuclease (APE) is a key enzyme involved in DNA base excision repair (BER) that is often expressed at elevated levels in human cancers. Pancreatic cancer cells treated with the nucleoside analogue gemcitabine $\left(2^{\prime}, 2^{\prime}\right.$-difluoro$2^{\prime}$ deoxycytidine) showed increases in APE/redox effector factor (ref-I) protein levels (approximately two-fold for Panc-I and six-fold for MiaPaCa-2), with corresponding increases in endonuclease activity. These results suggested that the activation of APE/ref-I might be an adaptive response that contributes to gemcitabine resistance by facilitating BER. To test this hypothesis, we examined the effects of disrupting APE/ref-I using antisense on gemcitabine toxicity. Antisense oligonucleotides decreased protein levels three-fold in MiaPaCa-2 and five-fold in Panc-I in comparison to controls, associated with reduced endonuclease activity. Combination treatments with antisense oligonucleotides and gemcitabine partially suppressed the increase in APE/ref-I activity seen in cells exposed to gemcitabine alone. While clonogenic assays showed only slight decreases in colony formation in cells treated with either antisense oligonucleotides or gemcitabine alone, the combination with APE/ref-I antisense resulted in a 2-log enhancement of gemcitabine toxicity in Panc-I cells. Overall these findings suggest that APE/ref-I plays a significant role in gemcitabine resistance in some pancreatic cancer cells, and support the further investigation of novel treatments that target this protein.

British Journal of Cancer (2004) 91, I I66- I 173. doi:I0.1038/sj.bjc.6602080 www.bjcancer.com

Published online 17 August 2004

(c) 2004 Cancer Research UK
\end{abstract}

Keywords: base excision repair; antisense; APE/ref-I; gemcitabine; pancreatic cancer; drug resistance

There are over 20000 apurinic/apyrimidinic (AP) sites formed per cell per day making it one of the most common forms of DNA damage (Evans et al, 2000; Kelley and Parsons, 2001). Abasic sites can arise due to spontaneous and chemically initiated hydrolysis through various conditions such as exposure to ionising radiation, oxidative stress or cytotoxic agents. The persistence of these abasic sites in DNA can lead to a halt in DNA replication, mutations and an overall loss in genetic stability.

The DNA base excision repair (BER) pathway is involved in maintaining DNA integrity through the removal and replacement of abasic sites (Evans et al, 2000). Once the damaged base has been identified by DNA glycosylases, the base is removed leaving an abasic site, which is hydrolysed by the apurinic/apyrimidinic endonuclease (APE) at position $5^{\prime}$ to the abasic site, leaving a $3^{\prime}$ hydroxyl and an abasic deoxyribose-5-phosphate. The abasic site is removed by deoxyribose phosphatase, then DNA polymerase $\beta$ and DNA ligase I or DNA ligase III/XRCCI replaces the nucleotide and closes the gaps between the newly synthesised nucleotide and the strand. Aside from BER, the APE protein is also involved in

*Correspondence: Dr DW Hedley, Department of Medical Oncology and Hematology, Princess Margaret Hospital, 610 University Avenue, Toronto, Ontario, Canada M5G 2M9; E-mail: david.hedley@uhn.on.ca Received I5 March 2004; revised 2 June 2004; accepted 21 June 2004; published online 17 August 2004 maintaining various transcription factors in their active reduced states such as AP-1, NF- $\kappa \mathrm{B}, \mathrm{HIF}-1$ and p53 (Hirota et al, 1997; Ema et al, 1999; Ueno et al, 1999). Therefore, APE is also commonly referred to as redox effector factor (ref-1) protein.

$\mathrm{APE} / \mathrm{ref}-1$ levels have been shown to be elevated in various types of cancers such as cervical, prostate, ovarian and germ cell tumours (Xu et al, 1997; Herring et al, 1998; Moore et al, 2000; Kelley et al, 2001; Robertson et al, 2001). Previous studies have shown that a decrease in APE/ref-1 protein renders mammalian cells sensitive to methyl methanesulphonate and hydrogen peroxide (Walker et al, 1994), while radioresistance of human cervical tumours directly correlates with increased APE/ref-1 expression (Herring et al, 1998). Following exposure to irradiation and oxidative stress, tumour cells showed elevated APE/ref-1 protein levels (Herring et al, 1998; Ramana et al, 1998; Silber et al, 2002), while overexpression of APE/ref-1 in testicular cancer resulted in bleomycin resistance (Robertson et al, 2001).

Attempts to create APE/ref-1 knockout mice (APEX-/-) were embryonically lethal, suggesting that APE/ref-1 is crucial for embryonic development (Xanthoudakis et al, 1996; Ludwig et al, 1998). Heterozygous APE/ref-1 mice (APEX + /-) were viable but abnormally sensitive to oxidative stress and prone to cancer development (Meira et al, 2001).

Pancreatic ductal adenocarcinoma is the fifth leading cause of cancer death in North America. It is highly resistant to 
conventional cytotoxic agents, and is almost $100 \%$ lethal. Currently, the only active agent appears to be a chain terminator, gemcitabine $\left(2^{\prime}, 2^{\prime}\right.$-difluoro-2'deoxycytidine), and there is an urgent need to develop new and more effective treatment (Abbruzzese, 2002; Haller, 2003). In this paper, we demonstrate that treatment of pancreatic cancer cells with gemcitabine significantly induces APE/ref-1 protein expression and endonuclease activity, and that the suppression of APE/ref-1 activity by antisense oligonucleotides produces a large increase in chemosensitivity in gemcitabine-treated Panc-1 cells.

\section{MATERIALS AND METHODS}

\section{Cell lines and culture}

The MiaPaCa-2 and Panc-1 human pancreatic cell lines (American Type Culture Collection, Rockville, MD, USA) were maintained in Dulbecco's medium with L-glutamine, $0.1 \mathrm{mg} \mathrm{ml}^{-1}$ kanamycin and $10 \%$ foetal bovine serum (FBS) (GibcoBRL, Burlington, Ontario, Canada). Cells were grown at $37^{\circ} \mathrm{C}$ and $5 \% \mathrm{CO}_{2}$ in a humidified atmosphere. Cell cultures were passaged routinely once a week and re-established from frozen stock every 2 months.

\section{Western blot analysis}

Protein was extracted from cells treated with lysis buffer containing protease inhibitor cocktail tablets (Roche Canada, Mississauga, Ontario, Canada), $50 \mathrm{~mm}$ HEPES ( $\mathrm{pH}=8.0), 10 \%$ glycerol, $1 \%$ Triton X-100, $150 \mathrm{~mm} \mathrm{NaCl}, 1 \mathrm{~mm}$ EDTA, $1.5 \mathrm{~mm}$ $\mathrm{MgCl}_{2}, 100 \mathrm{~mm} \mathrm{NaF}, 10 \mathrm{~mm} \mathrm{NaP} \mathrm{O}_{7} \cdot \mathrm{H}_{2} \mathrm{O}$ ) and centrifuged at 14000 r.p.m. at $4{ }^{\circ} \mathrm{C}$ for $10 \mathrm{~min}$. Samples were loaded in a $12 \%$ polyacrylamide gel, with $1 \times$ running buffer and allowed to run in a gel chamber (Bio-Rad Laboratories, Mississauga, Ontario, Canada). Following transfer to nitrocellulose membranes, these membranes were incubated in 1:1000 primary APE/ref-1 antibody (Novus Biologicals, Littleton, CO, USA) and probed with 1:2000 goat anti-mouse monoclonal antibody (Amersham Biosciences, Baie d'Urfé, Quebec, Canada). Membranes were exposed to ECL and developed on film (Kodak, New Haven, CT, USA), then stained and destained with amido black to determine protein loading.

\section{Flow cytometry analysis}

Cells were adjusted to $1 \times 10^{6}$ cells ml $^{-1}$ and fixed with $2 \%$ formaldehyde for $10 \mathrm{~min}$ at $37^{\circ} \mathrm{C}$, followed by $90 \%$ ice-cold methanol for $30 \mathrm{~min}$. Prior to antibody staining, cells were rinsed with $2 \mathrm{ml}$ phosphate-buffered saline (PBS) containing 4\% FBS. Based on a preliminary dilution curve showing that this concentration is saturating, $1: 1000$ dilution of APE/ref- 1 antibody (Novus Biologicals, Littleton, CO, USA) was added to the pellet for $30 \mathrm{~min}$ at room temperature, then washed twice in PBS plus $4 \%$ FBS. A goat-anti-mouse FITC-labelled secondary antibody (Caltag Laboratories, Burlingame, CA, USA) was added to the pellet for $15 \mathrm{~min}$ at room temperature, and the sample washed twice with PBS plus 4\% FBS and resuspended in $1 \mathrm{ml}$ of PBS plus 4\% FBS. Samples were analysed by flow cytometry (Epics Elite; BeckmanCoulter, Miami, FL, USA) using $488 \mathrm{~nm}$ excitation and collecting through a $525 \mathrm{~nm}$ bandpass filter. To standardise the flow cytometry results, calibration particles (Rainbow Beads; Spherotech Inc., Libertyville, IL, USA) were measured in each sample run. A calibration curve was generated based on the mean fluorescence values for the Rainbow Beads, as illustrated in Figure 1, and used to convert the mean fluorescence of the samples into the number of FITC molecules per cell.
A
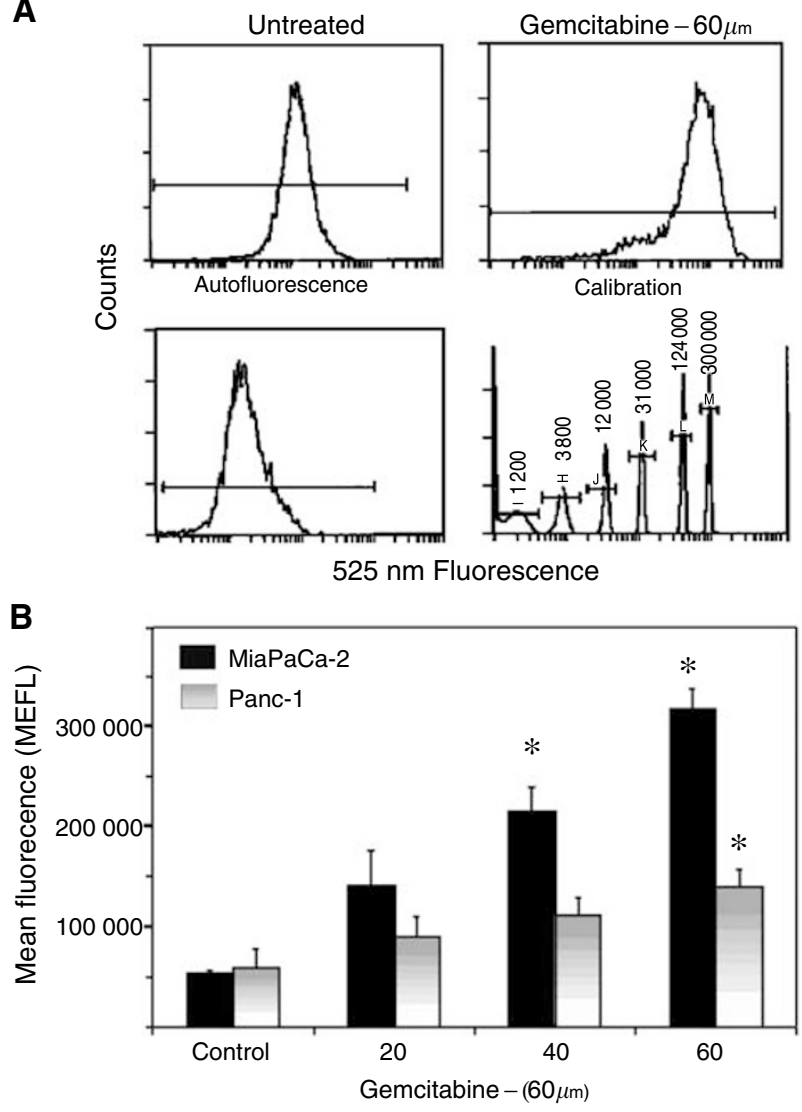

Figure I APE/ref-I protein levels in control and gemcitabine-treated MiaPaCa and Panc-I monolayers. (A) Representative flow cytometry data for MiaPaCa cells treated with $60 \mu \mathrm{M}$ gemcitabine for $48 \mathrm{~h}$ compared to untreated control, autofluorescence background and calibration beads. Gated on light scatter to exclude dead cells. (B) APE/ref-I protein levels in MiaPaCa and Panc-I controls and cells treated with 20, 40 and $60 \mu \mathrm{m}$ gemcitabine for $48 \mathrm{~h}$, expressed as mean equivalent fluorescein (MEFL) values obtained from the calibration beads. Bars represent means from three separate experiments \pm s.e. Stars indicate results that are statistically significant $(P<0.05)$ with respect to the nontreated samples.

\section{Gemcitabine treatment}

Gemcitabine was obtained from Eli Lilly \& Co (Indianapolis, IN, USA). Exponentially growing cells were plated at $\sim 10^{5}{\text { cells } \mathrm{ml}^{-1}}^{-1}$ in $\mathrm{T}-25 \mathrm{~cm}^{2}$ flasks, and drug added at desired concentrations to the medium and incubated for 24 or $48 \mathrm{~h}$. After treatment, cells were washed, harvested and counted for the preparation of cell lysates, or fixed for flow cytometry analysis.

\section{Transfection of antisense oligonucleotides}

Two antisense oligonucleotides were synthesised (ACGT, Toronto, Ontario, Canada) based on sequences recently published by Silber et al (2002). One antisense oligonucleotide targeted the translational start site of APE/ref-1 mRNA, while the other oligonucleotide targeted the exon-intron junction of the pre-mRNA. Oligonucleotides synthesised in the sense direction were used as controls. The oligonucleotides were transfected into cells of $60-$ $70 \%$ confluency. In one well of a 12 -well plate, $250 \mathrm{~nm}$ of each of the oligonucleotides was added along with $12 \mu \mathrm{l}$ of Plus Reagent (Invitrogen, Burlington, Ontario, Canada) and Opti-MEM media (Invitrogen, Burlington, Ontario, Canada) adjusted to a total volume of $100 \mu \mathrm{l}$ and allowed to stand for $15 \mathrm{~min}$ at room 
temperature. In another well, $4 \mathrm{ml}$ of Lipofectamine Reagent was added to $96 \mathrm{ml}$ of Opti-MEM media and allowed to stand for $15 \mathrm{~min}$. Precomplexed DNA was combined with the diluted Lipofectamine reagent and incubated at room temperature for 15 min. Growth medium was removed from flasks and DNAPlus-Lipofectamine Reagent complexes containing $800 \mu \mathrm{l}$ of fresh Opti-MEM media was added and mixed gently. Cells were allowed to incubate at $37^{\circ} \mathrm{C}$ at $5 \% \mathrm{CO}_{2}$ for $4 \mathrm{~h}$. Opti-MEM was then removed and replaced with normal growth medium containing $250 \mathrm{~nm}$ of each of the antisense oligonucleotides.

In order to measure the uptake kinetics for each oligonucleotide by flow cytometry and to determine the effects of lipofectamine, the translational start site targeting antisense oligonucleotide was labelled with FITC and the exon-intron targeting antisense oligonucleotide was labelled with Cy5.5. The flow cytometry technique was similar to that for APE/ref-1 protein measurement, with the additional use of a $633 \mathrm{~nm}$ HeNe laser to excite Cy5.5.

\section{Purification of APE/ref-1 protein}

Human APE/ref-1 wild-type protein was overproduced using the pGEX-3X (Pharmacia Biotech, Uppsala, Sweden) system utilising the BamHI $5^{\prime}$ and EcoRI $3^{\prime}$ restriction sites, obtained from Dr Mark Kelley (Indiana University). The transformations were performed using One Shot ${ }^{\circledR}$ TOP 10 Competent Cells (Invitrogen, Burlington, Ontario, Canada) with transformed Escherichia coli cells spread on Luria-Bertani (LB) agar plates containing ampicillin. Colonies found to contain the transformed plasmid were placed in LB broth containing $100 \mu \mathrm{g} \mathrm{ml}^{-1}$ ampicillin and incubated overnight at $37^{\circ} \mathrm{C}$. For batch purification of protein, $200 \mu \mathrm{l}$ of glutathione sepharose 4B slurry (Amersham Biosciences, Baie d'Urfé, Quebec, Canada) was equilibriated and the bacterial sonicate allowed to incubate at room temperature for $30 \mathrm{~min}$. To sediment the gel, glutathione elution buffer was added, mixed gently and then centrifuged at $500 \mathrm{~g}$ for $5 \mathrm{~min}$. The supernatant was then dialysed for $2 \mathrm{~h}$ at $4^{\circ} \mathrm{C}$ in 100 volumes of GST. The concentration of the GST-tagged protein was determined by assuming 1 absorbance unit at $280 \mathrm{~nm}$ was equal to $0.5 \mathrm{mg} \mathrm{ml}^{-1}$. The purified APE/ref-1 protein was stored in aliquots at $-20^{\circ}$ and used as the positive control in the endonuclease assay.

\section{Endonuclease assay}

A 26-mer oligonucleotide (IDT Technologies, Coralville, IA, USA) containing a tetrahydrofuran $(\mathrm{F})$ residue at position 15 was used, as described by Kelley et al (2001) and Kelley and Parsons (2001). Following ${ }^{32} \mathrm{P}$ labelling, the oligonucleotide was purified using a G25 column and then annealed to a complementary oligonucleotide. Based on $2.0 \times 10^{5}$ cells lysed, $1 \mu \mathrm{l}$ of total cell extract was added to $10 \mu \mathrm{l}$ reaction volume containing 5000 c.p.m. of labelled double-stranded $\mathrm{F}$ oligonucleotide in $50 \mathrm{~mm}$ HEPES, $50 \mathrm{~mm} \mathrm{KCl}$, $10 \mathrm{mM} \mathrm{MgCl}_{2}, 2 \mathrm{~mm}$ DTT, $1 \mu \mathrm{g} \mathrm{ml}^{-1}$ bovine serum albumin and $0.05 \%$ Triton $\mathrm{X}-100$, adjusted to $\mathrm{pH}$ 7.5. Reactions were allowed to proceed for $5 \mathrm{~min}$ in a $37^{\circ} \mathrm{C}$ water bath and stopped by adding $4 \mu \mathrm{l}$ of $96 \%$ formamide, $10 \mathrm{~mm}$ EDTA and bromophenol blue. The positive control was the purified APE/ref-1 protein $(0.5-2.0 \mu \mathrm{g})$, and the negative control consisted of cells treated with the BER inhibitor methoxyamine hydrochloride $33 \mathrm{~mm}$ (Sigma-Aldrich Canada Ltd, Oakville, Ontario, Canada) mixed in buffer containing $50 \mathrm{mM} \mathrm{KPO}_{4}$, (pH 7.1), and exposed to double-stranded oligonucleotide for $15 \mathrm{~min}$ in a $37^{\circ} \mathrm{C}$ water bath prior to adding lysate. Samples were separated with a $15 \%$ polyacrylamide gel containing $7 \mathrm{M}$ urea and exposed to a Molecular Dynamics Phosphoimager to measure the intensities of the substrate and product bands, and to film overnight for visualisation. Calculation of the fraction of product formed was based on Fraction of product formed = Area product/(Area product + Area substrate).

\section{Clonogenic assay}

Aliquots of $10^{5}$ cells were taken from cell suspensions treated with antisense or sense oligonucleotides and/or gemcitabine and diluted serially in growth medium post-treatment, plated in six-well cell culture plates (Gibco BRL, Burlington, Ontario, Canada) at final cell densities of $10^{4}, 10^{3}$ and $10^{2}$ cells well ${ }^{-1}$. After 7 and 12 days of incubation at $37^{\circ} \mathrm{C}$ in $95 \%$ air and $5 \% \mathrm{CO}_{2}$ for $\mathrm{MiaPaCa}-2$ and Panc-1, respectively, medium was removed and plates allowed to air dry. Colonies were counter-stained with methylene blue in $70 \%$ ethanol for $5 \mathrm{~min}$ and counted.

\section{Statistical analysis}

Statistical analyses were performed with Jandel Sigma Stat software, Version 2.0. For comparisons between treatments, the analysis of variance test of equal variance or Kruskal-Wallis was applied with the Dunnett's method. A $P$-value of $\alpha=0.05$ indicated statistical significance.

\section{RESULTS}

\section{Gemcitabine effects on APE/ref-1 protein}

Preliminary experiments showed that both cell lines maintained $>90 \%$ viability, based on flow cytometric assessment of light scatter and propidium iodide exclusion, following exposure to up to $60 \mu \mathrm{m}$ gemcitabine for up to $48 \mathrm{~h}$. To examine whether gemcitabine was able to induce APE/ref-1 levels, MiaPaCa-2 and Panc- 1 cells were treated with a range of gemcitabine concentrations for 24 or $48 \mathrm{~h}$, and APE/ref-1 protein levels measured using Western blot or flow cytometry. Preliminary experiments showed that these two techniques gave comparable results. However, the flow cytometry method was more rapid and easier to standardise and was therefore used for most experiments. As shown in Figure 1, the two cell lines showed similar basal levels of APE/ref-1, and each showed a gemcitabine dose-dependent increase following $48 \mathrm{~h}$ of continuous treatment. Relative to untreated controls, MiaPaCa-2 cells treated with 40 and $60 \mu \mathrm{m}$ of gemcitabine showed four- and six-fold increases in APE/ref-1 protein expression $(P=0.012$ and 0.003 , respectively), while Panc- 1 cells treated with $60 \mu \mathrm{M}$ of gemcitabine showed a two-fold increase $(P=0.047)$. Smaller increases in APE/ref-1 were also seen after $24 \mathrm{~h}$ treatment with gemcitabine in both cell lines (data not shown).

\section{In vitro assessment of APE/ref-1 endonuclease activity of gemcitabine-treated cells}

To examine the effects on endonuclease activity, MiaPaCa-2 and Panc-1 cells were treated with various concentrations of gemcitabine for $48 \mathrm{~h}$, then lysed and assayed for catalytic activity. More 14mer product was formed, with a corresponding decrease in 26-mer substrate, at increasing concentrations of gemcitabine (Figure 2A). Both cell lines showed dose-dependent increases in endonuclease activity following treatment with gemcitabine (Figure 2B). Using $60 \mu \mathrm{M}$ of gemcitabine, the levels were six-fold greater $(P<0.05)$ than control for MiaPaCa-2 and two-fold greater $(P<0.05)$ than control for Panc-1. MiaPaCa-2 and Panc-1 monolayers were treated with gemcitabine for $48 \mathrm{~h}$ and samples for protein expression and endonuclease activity were taken from the same flask to determine the correlation between endonuclease activity and APE/ref-1 protein expression. As shown in Figure 3, these values were highly correlated in both MiaPaCa-2 $(r=0.951)$ and Panc-1 $(r=0.999)$. 
A

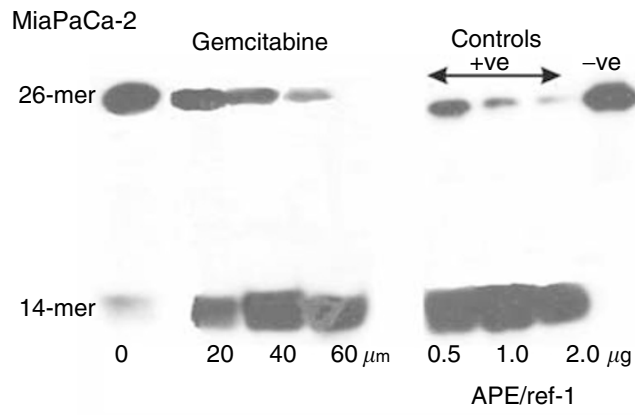

Panc-1

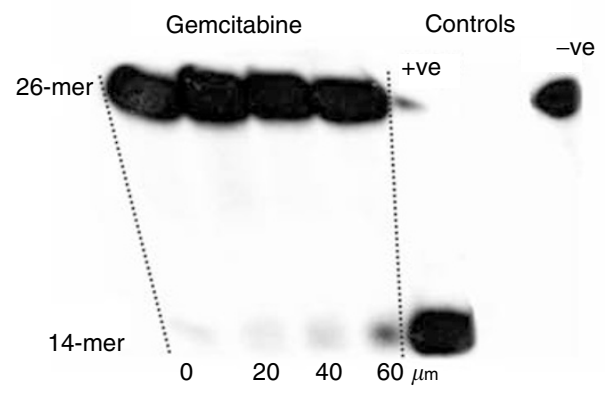

B

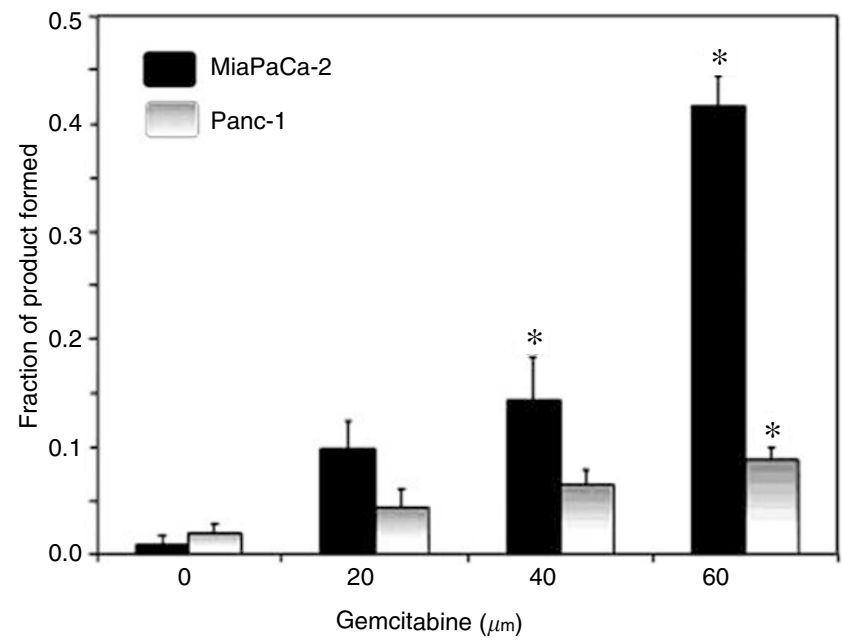

Figure 2 Endonuclease activity present in gemcitabine-treated cells. (A) Film images of 26-mer substrate vs I4-mer product in MiaPaCa and Panc-I cells after various doses of gemcitabine for $48 \mathrm{~h}$. Positive controls consisted of purified recombinant APE/ref-I protein and negative controls included the BER inhibitor methoxyamine. (B) Range of gemcitabine concentrations vs the fraction of 14-mer product formed. Stars indicate results that are statistically significant $(P<0.05)$ with respect to the nontreated samples. The concentration of gemcitabine is expressed as $\mu \mathrm{M}$. All values are means of three independent experiments \pm s.e.

\section{Uptake kinetics of fluorescently labelled antisense oligonucleotides}

The antisense oligonucleotide targeting the translational start site of APE/ref-1 mRNA was labelled with FITC, while the other antisense oligonucleotide targeting the exon-intron junction of APE/ref-1 pre-mRNA was labelled with Cy5.5. Subcellular localisation of the antisense oligonucleotides was examined using fluorescence microscopy and the translational start site targeting

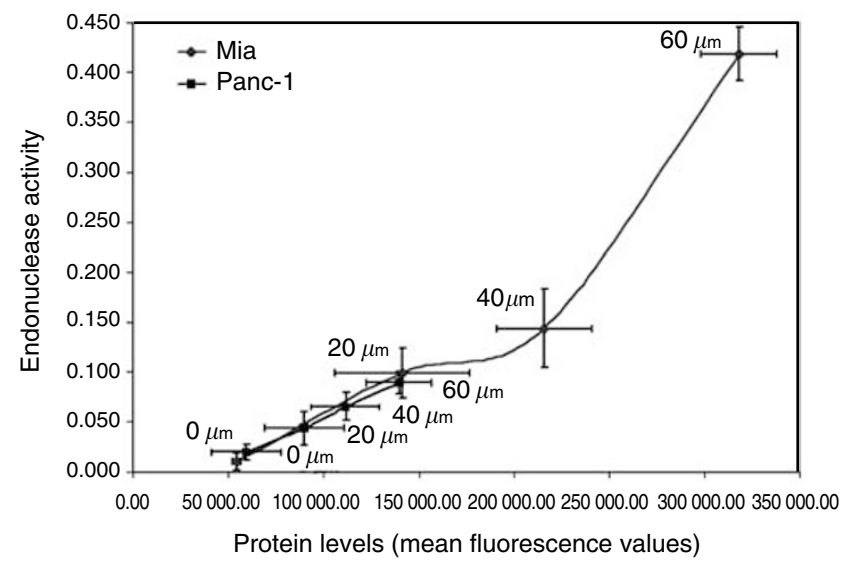

Figure 3 Relationship between APE/ref-I protein level vs endonuclease activity postgemcitabine exposure. MiaPaCa (diamonds) and Panc-I (squares) cells were treated with various doses of gemcitabine for $48 \mathrm{~h}$. Samples from the same flask were collected and assessed using both flow cytometry and endonuclease assay. Points represent mean values from three separate experiments and error bars are standard error of the mean; $r=0.951$ (MiaPaCa) and 0.999 (Panc-I).

antisense was found in the cytoplasm, while the exon-intron targeting antisense oligonucleotide was located in the nucleus (Figure 4). Preliminary experiments using flow cytometry showed very low levels of fluorescently labelled oligonucleotide uptake in the control cells relative to lipofectamine-treated cells (data not shown). With lipofectamine, the uptake of both antisense oligonucleotides appeared to saturate at concentrations above $250 \mathrm{~nm}$. Based on the flow cytometry calibration beads, the mean fluorescence values for cells transfected at this concentration correspond to approximately $4 \times 10^{5}$ oligonucleotides cell $^{-1}$ for the FITC-labelled construct. A concentration of $250 \mathrm{nM}$ of each antisense oligonucleotide was chosen for future experiments.

\section{Effects of APE/ref-1 antisense on protein expression and endonuclease activity}

Both cell lines were transfected with antisense or sense oligonucleotides and APE/ref-1 protein levels were analysed 12, 24, 48 and $72 \mathrm{~h}$ post-transfection. Using both Western blot and flow cytometry, there were statistically significant decreases in protein levels detected after $24 \mathrm{~h}$ of transfection with MiaPaCa-2 decreasing three-fold $(P<0.001)$ and Panc-1 decreasing four-fold $(P<0.001)$. After $48 \mathrm{~h}$ post-transfection, the APE/ref-1 levels had substantially recovered. The level of endonuclease activity was assessed in cell lysates, obtained from the same flasks as the samples taken for protein measurements. As illustrated in Figure 5, a reduction in the amount of 14-mer product formed $v s$ substrate was seen $24 \mathrm{~h}$ post-transfection, with recovery of endonuclease activity at $48 \mathrm{~h}$, consistent with the decrease in protein levels. Treatment with oligonucleotides that were synthesised in the sense direction had no significant effects on APE/ref-1 protein levels or endonuclease activity.

\section{APE/ref-1 protein and endonuclease activity in gemcitabine-treated cells: effects of antisense}

To examine if APE/ref- 1 antisense was able to suppress the increases in protein levels and endonuclease activity seen following treatment with gemcitabine, experiments involving the treatment of cells with both antisense oligonucleotides and gemcitabine were performed. Both MiaPaCa-2 and Panc- 1 cell lines were transfected with antisense or sense oligonucleotides for 12 and $24 \mathrm{~h}$ with some samples receiving an additional $24 \mathrm{~h}$ treatment of $20 \mu \mathrm{M}$ of 
Translational start

FITC

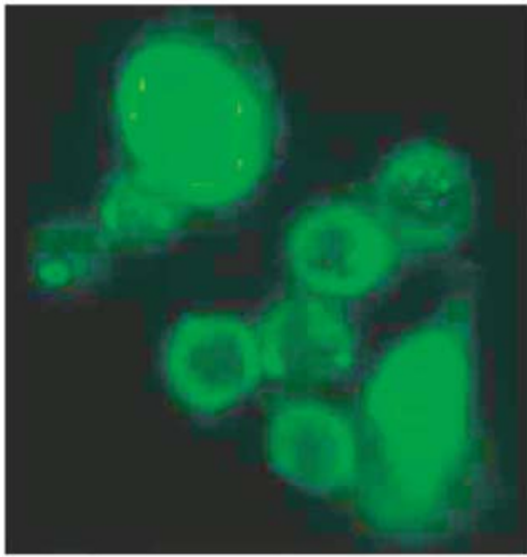

Exon - intron

Cy 5.5
Overlay

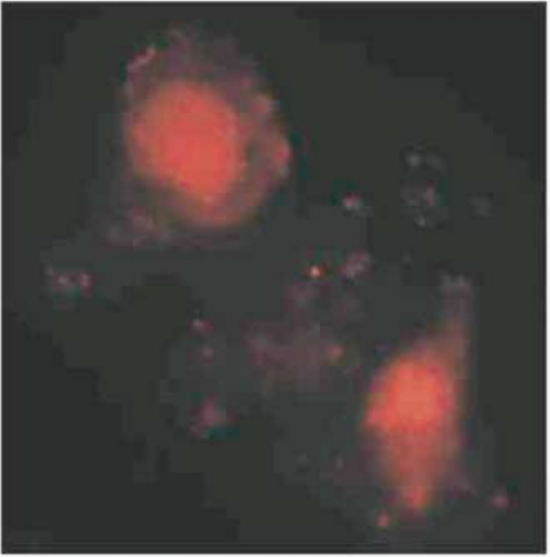

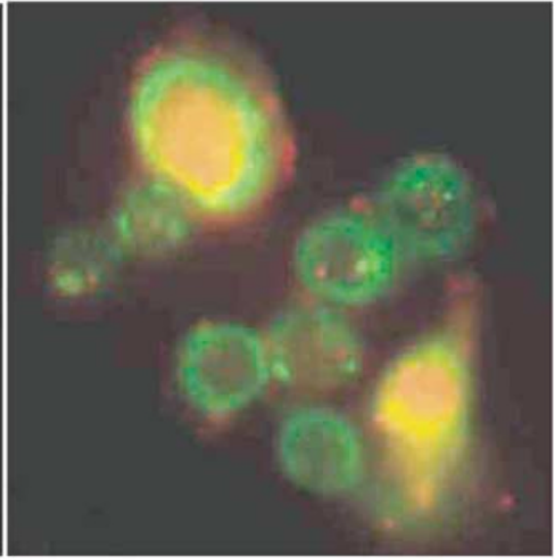

Figure 4 Subcellular localisation of fluorescence-labelled antisense oligonucleotides. That targeting the exon-intron junction of APE/ref-I pre-mRNA is localised in the nucleus, whereas the translational start is cytoplasmic.

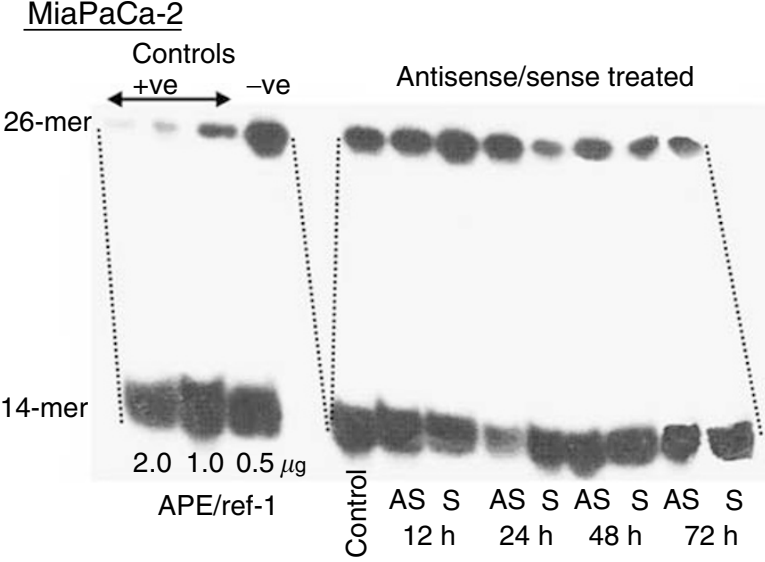

Panc-1

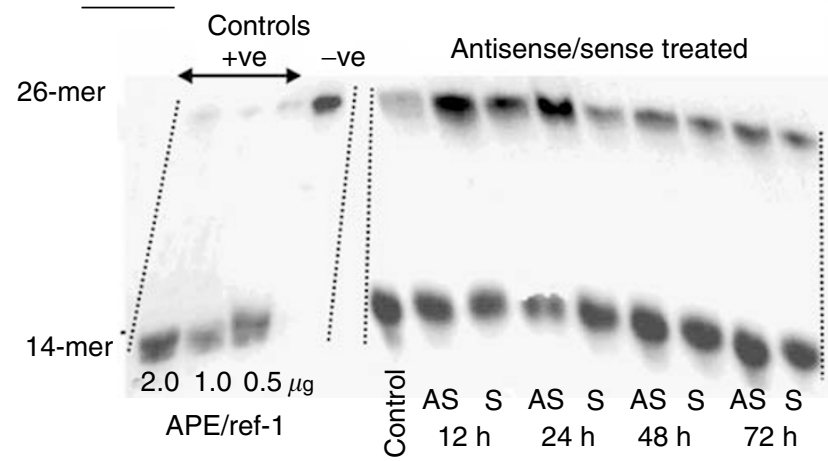

Figure 5 Endonuclease activity of MiaPaCa and Panc-I cells treated with antisense oligonucleotides. The MiaPaCa and Panc-I cell lines were exposed to antisense or sense oligonucleotides for various time points. Cell lysates were collected and analysed using the endonuclease assay. C - control; AS - antisense; S - sense.

gemcitabine. There was a decrease in APE/ref-1 induction when the cells were transfected with antisense prior to gemcitabine exposure, relative to the samples treated with gemcitabine alone or gemcitabine plus oligonucleotides synthesised in the sense direction (Figure 6A). Similarly, endonuclease activity was lower in the cells transfected with antisense oligonucleotides prior to gemcitabine treatment $v s$ the cells treated with gemcitabine alone (Figure 6B).

\section{In vitro sensitivity of APE/ref- 1 antisense-treated Panc-1 and MiaPaCa-2 cells to gemcitabine}

Colony-forming assays were performed on both cell lines treated with antisense or sense oligonucleotides and gemcitabine. The MiaPaCa-2 cells were found to be more gemcitabine sensitive than Panc-1 in the clonogenic assay in preliminary experiments, and the dose was therefore reduced to $5 \mu \mathrm{M}$ for MiaPaCa-2. Samples were also treated with gemcitabine for $24 \mathrm{~h}$ prior to transfection with antisense to determine whether the order of administration influenced clonogenic survival. As shown in Figure 7, lower numbers of colonies were formed by MiaPaCa-2 and Panc-1 cells treated with antisense alone, gemcitabine alone or the combination, when compared to cells treated with sense oligonucleotides or untreated controls $(P<0.05)$. Gemcitabine-treated Panc- 1 cell lines showed a 2-log decrease in colony formation when the cells were pretreated for $24 \mathrm{~h}$ with antisense oligonucleotides compared to cells treated with gemcitabine alone or in combination with the sense oligonucleotides (Figure 7A). Despite the suppression of APE/ref-1 activity in MiaPaCa-2 cells treated with antisense, the effects on gemcitabine sensitivity relative to the sense construct were much smaller and not statistically significant (Figure 7B).

\section{DISCUSSION}

In this study, we show that gemcitabine is capable of inducing APE/ref- 1 levels in two pancreatic cancer cell lines, MiaPaCa- 2 and Panc-1. The increase in APE/ref-1 protein levels was closely correlated with an increase in endonuclease activity, suggesting that $\mathrm{APE} / \mathrm{ref}-1$ is the predominant endonuclease enzyme in these cells. These results suggest the existence of a cellular response that might facilitate the repair of gemcitabine-induced DNA damage, potentially thereby enhancing drug resistance. To investigate this further, we examined the effects of antisense oligonucleotides against APE/ref-1 mRNA, using constructs recently described by Silber et al (2002) and treatment schedules based on initial experiments that measured the uptake of fluorescence-labelled 
A

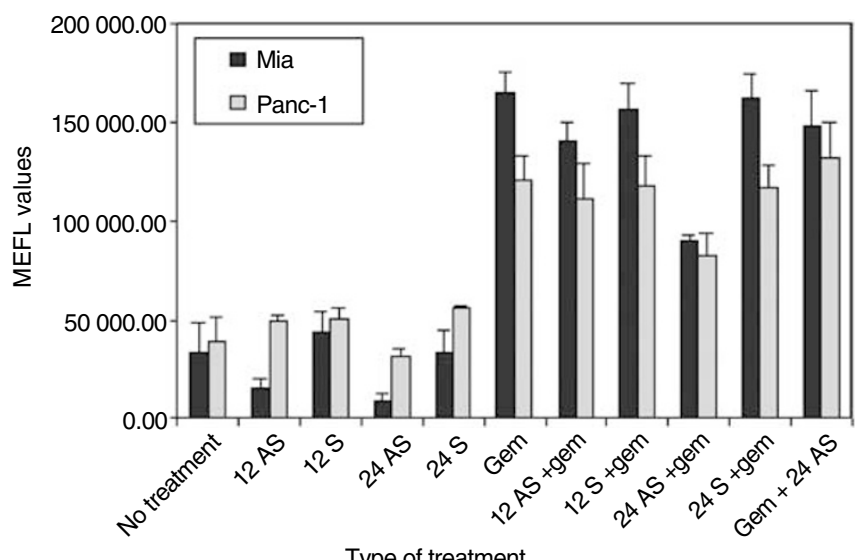

B

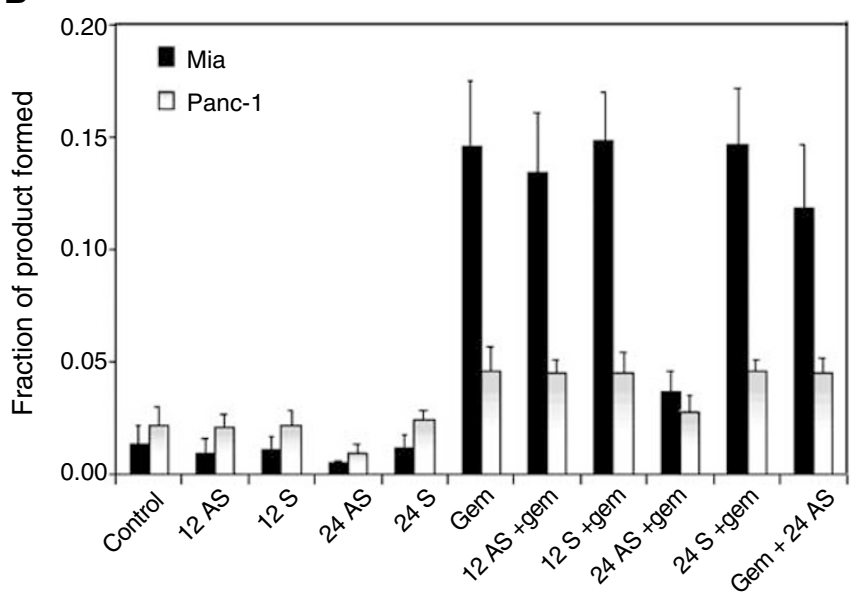

Type of treatment

Figure 6 APE/ref-I protein levels $(\mathbf{A})$ and endonuclease activity $(\mathbf{B}$ post-treatment with antisense/sense oligonucleotide \pm gemcitabine. (A) Protein levels. MiaPaCa (dark bars) and Panc-I (light bars) cells were treated with antisense or sense oligonucleotides $\pm 20 \mu \mathrm{M}$ gemcitabine. APE/ ref-I protein levels were accessed at 12 or $24 \mathrm{~h}$ post-transfection of oligonucleotides or $24 \mathrm{~h}$ post-treatment with gemcitabine. As indicated, some samples were treated with gemcitabine prior to transfection with antisense oligonucleotides to determine whether the sequence of treatment affected outcome. Bars represent three individual experiments, with error bars representing standard error of the mean. AS - antisense; $S$ - sense; Gem - gemcitabine.

oligonucleotides. These antisense oligonucleotides were able to suppress gemcitabine-induced APE/ref-1 activity when given prior to but not following gemcitabine treatment. We avoided exposure to gemcitabine immediately following treatment with lipofectamine, and the data shown in Figure 6 were obtained 36 and $48 \mathrm{~h}$ following antisense treatment. Since the maximum effect of the antisense oligonucleotides was seen at $24 \mathrm{~h}$, the effects on APE/ref1 in combination with gemcitabine might be underestimated. Panc-1 cells, which were highly resistant to gemcitabine based on clonogenic assay, showed a large enhancement in gemcitabine toxicity when treated with APE/ref-1 antisense. This finding of enhanced sensitivity to a DNA-damaging agent is similar to but greater than earlier results obtained by Walker et al (1994) using stable transfectants of the full-length APE/ref-1 antisense and the more recent results obtained by Silber et al (2002) using phosphorothioate antisense oligonucleotides. However, although MiaPaCa-2 cells showed similar responses to those seen in Panc-1 following treatment with gemcitabine and antisense in terms of APE/ref-1 protein levels and endonuclease activity, the sensitisa-

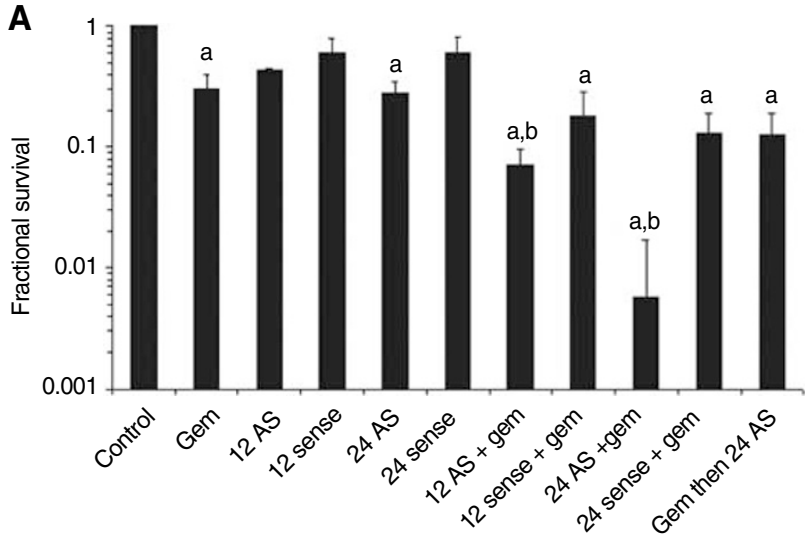

Type of treatment

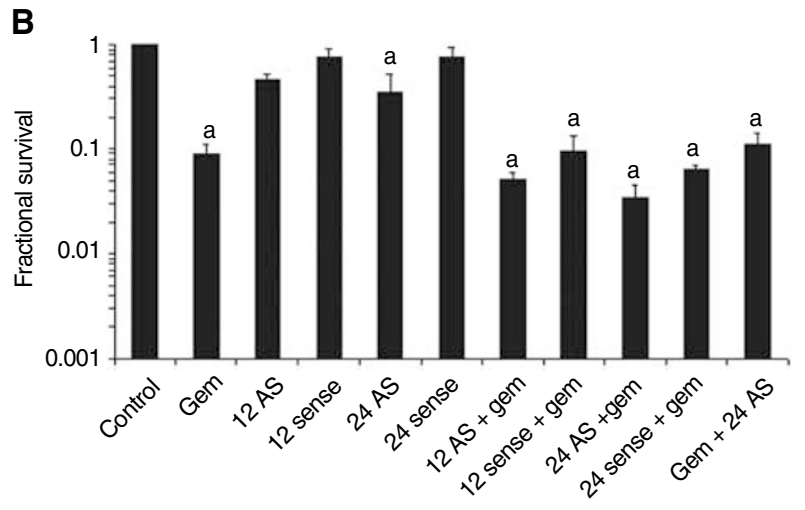

Type of treatment

Figure 7 Clonogenic survival of (A) Panc-I and (B) MiaPaCa cells treated with gemcitabine alone, with antisense (AS) or sense oligonucleotide for 12 or $24 \mathrm{~h}$ or the combination. Bars represent at least three individual experiments, with standard error of the mean indicated by the

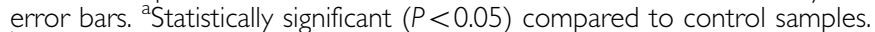
${ }^{b}$ Statistically significant $(P<0.05)$ with respect to the gemcitabine-only treated samples.

tion to gemcitabine by the antisense was small and not statistically significant relative to the sense control.

The effects of gemcitabine on APE/ref-1 protein induction seen in the present study are greater than those previously reported involving oxidative stress or $\gamma$-irradiation (Herring et al, 1998; Ramana et al, 1998; Silber et al, 2002). However, to our knowledge this study is the first to address the effects of deoxynucleoside analogues on APE/ref-1 activity. It should be noted that although the concentrations of gemcitabine used in these experiments approximate the peak plasma levels achieved using standard dose schedules, the continuous exposure for $48 \mathrm{~h}$ exceeds that seen in cancer patients. Therefore, it remains to be determined if APE/ref1 activity is increased during treatment with gemcitabine in the clinic. In preliminary experiments, we have found that another deoxycytidine analogue, cytosine arabinoside (ara-C), is able to elevate APE/ref-1 levels in OCI/AML-2 leukaemia cells (not shown), suggesting that this might be a widespread response to treatment with deoxynucleoside analogues.

Previous studies have demonstrated elevated levels of another BER protein, DNA ligase I, in MiaPaCa- 2 cells treated with ara-C and gemcitabine (Gandhi et al, 1996; Gandhi et al, 1997). The enhancement of DNA ligase I protein due to ara-C exposure was not accompanied by increased DNA synthesis or polymerase activity. DNA ligase I levels returned to normal as the drug-treated cells resumed DNA synthesis, thus strongly suggesting the 
increased DNA ligase I levels were involved in repair of DNA damage caused by ara-C, rather than DNA replication (Sun et al, $2002 a, b)$. Also, it has been previously shown that the antisense oligonucleotides used in the present paper are able to reduce APE/ ref- 1 protein and endonuclease activity in human glioma cells, with concurrent reduction in resistance towards the alkylating agents methyl methanesulphonate and temozolomide (Silber et al, 2002). Another study examining the effects of methoxyamine, an inhibitor of BER through binding of abasic sites, found that this enhanced sensitivity to temozolomide in human colon cancer xenografts (Liu et al, 2002). Taken together, these studies suggest that the BER pathway plays an important role in cancer chemotherapy resistance, and that suppression of BER might therefore result in increased chemosensitivity.

The enhancement of APE/ref-1 activity following gemcitabine treatment suggests that this might be playing a role in the repair of DNA damage, although we recognise that it is unclear if APE/ref-1 acts on misincorporation of gemcitabine into DNA. The present series of experiments does not establish that the sensitising effects of APE/ref-1 antisense is due to suppression of its BER activity, since APE/ref-1 also acts as a redox regulator of several transcription factors including NF- $\kappa \mathrm{B}$ and AP1 that can promote cell survival responses (Hirota et al, 1997; Arrigo, 1999; Ueno et al, 1999; Moos et al, 2003). For example, the activation of NF- $\kappa \mathrm{B}$ can occur during treatment with cancer chemotherapy and is believed to promote drug resistance (Wang et al, 1999; Baldwin, 2001; Arlt et al, 2003). The increases in APE/ref-1 seen in pancreas cancer cells during treatment with gemcitabine might augment this NF- $\kappa \mathrm{B}$ response, additional to any effects on BER. The BER and redox effector activities of APE/ref-1 can be differentially regulated by phosphate modifications, and each function involves complex interactions with other cellular proteins (Yacoub et al, 1997; Evans et al, 2000; Hsieh et al, 2001). The striking difference observed between the sensitisation of Panc-1 and MiaPaCa-2 cells to gemcitabine following APE/ref-1 antisense treatment is likely to be explained on the basis of differences involving these elements, and further work is needed in this area.

Phosphorothioate antisense olignonucleotides have been developed as therapeutic agents targeting a number of genes involved in cancer development, and several are currently undergoing clinical trial (O’Dwyer et al, 1999; Morris et al, 2002). Using APE/ref-1 antisense, we obtained a two decade decrease in the clonogenic survival of highly resistant Panc-1 cells treated with gemcitabine. Although it is not known if clinically achievable gemcitabine levels can upregulate APE/ref-1 activity in cancer patients, or if selective targeting of APE/ref-1 would enhance the therapeutic index of gemcitabine in pancreas cancer patients, they warrant further investigation including in vivo testing in xenograft models, examination of other pancreas cancer cell lines and elucidation of the underlying mechanisms. This work is currently in progress in our laboratory.

\section{ACKNOWLEDGEMENTS}

We wish to thank Dr Mark Kelley, Indiana University, for his kind donation of the APE/ref-1 expression vector and helpful advice. This work was supported by grants from the National Cancer Institute of Canada, raised in part by the Terry Fox Run.

\section{REFERENCES}

Abbruzzese JL (2002) Past and present treatment of pancreatic adenocarcinoma: chemotherapy as a standard treatment modality. Semin Oncol 29: $2-8$

Arlt A, Gehrz A, Muerkoster S, Vorndamm J, Kruse ML, Folsch UR, Schafer $\mathrm{H}$ (2003) Role of NF-kappaB and Akt/PI3K in the resistance of pancreatic carcinoma cell lines against gemcitabine-induced cell death. Oncogene 22: $3243-3251$

Arrigo AP (1999) Gene expression and the thiol redox state. Free Radic Biol Med 27: $936-944$

Baldwin AS (2001) Control of oncogenesis and cancer therapy resistance by the transcription factor NF-kappaB. J Clin Invest 107: 241-246

Ema M, Hirota K, Mimura J, Abe H, Yodoi J, Sogawa K, Poellinger L, Fujii-Kuriyama Y (1999) Molecular mechanisms of transcription activation by HLF and HIF1alpha in response to hypoxia: their stabilization and redox signal-induced interaction with $\mathrm{CBP} / \mathrm{p} 300 . E M B O$ J 18: $1905-1914$

Evans AR, Limp-Foster M, Kelley MR (2000) Going APE over ref-1. Mutat Res 461: $83-108$

Gandhi V, Huang P, Chapman AJ, Chen F, Plunkett W (1997) Incorporation of fludarabine and 1-beta-D-arabinofuranosylcytosine 5'-triphosphates by DNA polymerase alpha: affinity, interaction, and consequences. Clin Cancer Res 3: $1347-1355$

Gandhi V, Legha J, Chen F, Hertel LW, Plunkett W (1996) Excision of $2^{\prime}, 2^{\prime}$ difluorodeoxycytidine (gemcitabine) monophosphate residues from DNA. Cancer Res 56: $4453-4459$

Haller DG (2003) Chemotherapy for advanced pancreatic cancer. Int $J$ Radiat Oncol Biol Phys 56: 16-23

Herring CJ, West CM, Wilks DP, Davidson SE, Hunter RD, Berry P, Forster G, MacKinnon J, Rafferty JA, Elder RH, Hendry JH, Margison GP (1998) Levels of the DNA repair enzyme human apurinic/ apyrimidinic endonuclease (APE1, APEX, Ref-1) are associated with the intrinsic radiosensitivity of cervical cancers. $\mathrm{Br} J$ Cancer 78: $1128-1133$

Hirota K, Matsui M, Iwata S, Nishiyama A, Mori K, Yodoi J (1997) AP-1 transcriptional activity is regulated by a direct association between thioredoxin and Ref-1. Proc Natl Acad Sci USA 94: 3633-3638
Hsieh MM, Hegde V, Kelley MR, Deutsch WA (2001) Activation of APE/ Ref-1 redox activity is mediated by reactive oxygen species and $\mathrm{PKC}$ phosphorylation. Nucleic Acids Res 29: 3116-3122

Kelley MR, Cheng L, Foster R, Tritt R, Jiang J, Broshears J, Koch M (2001) Elevated and altered expression of the multifunctional DNA base excision repair and redox enzyme Ape1/ref- 1 in prostate cancer. Clin Cancer Res 7: $824-830$

Kelley MR, Parsons SH (2001) Redox regulation of the DNA repair function of the human AP endonuclease Ape1/ref-1. Antioxid Redox Signal 3: $671-683$

Liu L, Nakatsuru Y, Gerson SL (2002) Base excision repair as a therapeutic target in colon cancer. Clin Cancer Res 8: 2985-2991

Ludwig DL, MacInnes MA, Takiguchi Y, Purtymun PE, Henrie M, Flannery M, Meneses J, Pedersen RA, Chen DJ (1998) A murine AP-endonuclease gene-targeted deficiency with post-implantation embryonic progression and ionizing radiation sensitivity. Mutat Res 409: 17-29

Meira LB, Devaraj S, Kisby GE, Burns DK, Daniel RL, Hammer RE, Grundy S, Jialal I, Friedberg EC (2001) Heterozygosity for the mouse Apex gene results in phenotypes associated with oxidative stress. Cancer Res 61: $5552-5557$

Moore DH, Michael H, Tritt R, Parsons SH, Kelley MR (2000) Alterations in the expression of the DNA repair/redox enzyme APE/ref-1 in epithelial ovarian cancers. Clin Cancer Res 6: 602-609

Moos PJ, Edes K, Cassidy P, Massuda E, Fitzpatrick FA (2003) Electrophilic prostaglandins and lipid aldehydes repress redox-sensitive transcription factors p53 and hypoxia-inducible factor by impairing the selenoprotein thioredoxin reductase. J Biol Chem 278: $745-750$

Morris MJ, Tong WP, Cordon-Cardo C, Drobnjak M, Kelly WK, Slovin SF, Terry KL, Siedlecki K, Swanson P, Rafi M, DiPaola RS, Rosen N, Scher HI (2002) Phase I trial of BCL-2 antisense oligonucleotide (G3139) administered by continuous intravenous infusion in patients with advanced cancer. Clin Cancer Res 8: 679-683

O’Dwyer PJ, Stevenson JP, Gallagher M, Cassella A, Vasilevskaya I, Monia BP, Holmlund J, Dorr FA, Yao KS (1999) c-Raf-1 depletion and tumor responses in patients treated with the c-raf-1 antisense oligodeoxynucleotide ISIS 5132 (CGP 69846A). Clin Cancer Res 5: 3977-3982 
Ramana CV, Boldogh I, Izumi T, Mitra S (1998) Activation of apurinic/ apyrimidinic endonuclease in human cells by reactive oxygen species and its correlation with their adaptive response to genotoxicity of free radicals. Proc Natl Acad Sci USA 95: 5061 - 5066

Robertson KA, Bullock HA, Xu Y, Tritt R, Zimmerman E, Ulbright TM, Foster RS, Einhorn LH, Kelley MR (2001) Altered expression of Ape1/ref1 in germ cell tumors and overexpression in NT2 cells confers resistance to bleomycin and radiation. Cancer Res 61: 2220-2225

Silber JR, Bobola MS, Blank A, Schoeler KD, Haroldson PD, Huynh MB, Kolstoe DD (2002) The apurinic/apyrimidinic endonuclease activity of Ape1/Ref-1 contributes to human glioma cell resistance to alkylating agents and is elevated by oxidative stress. Clin Cancer Res 8: $3008-3018$

Sun D, Urrabaz R, Buzello C, Nguyen M (2002a) Induction of DNA ligase I by 1-beta-D-arabinosylcytosine and aphidicolin in MiaPaCa human pancreatic cancer cells. Exp Cell Res 280: 90 -96

Sun D, Urrabaz R, Kelly S, Nguyen M, Weitman S (2002b) Enhancement of DNA ligase I level by gemcitabine in human cancer cells. Clin Cancer Res 8: $1189-1195$
Ueno M, Masutani H, Arai RJ, Yamauchi A, Hirota K, Sakai T, Inamoto T, Yamaoka Y, Yodoi J, Nikaido T (1999) Thioredoxin-dependent redox regulation of p53-mediated p21 activation. J Biol Chem 274: 35809-35815

Walker LJ, Craig RB, Harris AL, Hickson ID (1994) A role for the human DNA repair enzyme HAP1 in cellular protection against DNA damaging agents and hypoxic stress. Nucleic Acids Res 22: 4884-4889

Wang CY, Cusack Jr JC, Liu R, Baldwin Jr AS (1999) Control of inducible chemoresistance: enhanced anti-tumor therapy through increased apoptosis by inhibition of NF-kappaB. Nat Med 5: 412-417

Xanthoudakis S, Smeyne RJ, Wallace JD, Curran T (1996) The redox/DNA repair protein, Ref-1, is essential for early embryonic development in mice. Proc Natl Acad Sci USA 93: 8919-8923

Xu Y, Moore DH, Broshears J, Liu L, Wilson TM, Kelley MR (1997) The apurinic/apyrimidinic endonuclease (APE/ref-1) DNA repair enzyme is elevated in premalignant and malignant cervical cancer. Anticancer Res 17: $3713-3719$

Yacoub A, Kelley MR, Deutsch WA (1997) The DNA repair activity of human redox/repair protein APE/Ref-1 is inactivated by phosphorylation. Cancer Res 57: 5457-5459 